\title{
Eksplorasi Antibakteri dari Kapang Tanah Arboretum
}

\section{(Exploration of Antibacteria from Soil Mold in Arboretum)}

\author{
Rizal Dwinto Rochman ${ }^{1 *}$, Titiek Sunartatie ${ }^{2}$, Usamah Afiff ${ }^{2}$ \\ (Diterima Agustus 2019/Disetujui Mei 2020)
}

\begin{abstract}
ABSTRAK
Penelitian untuk menemukan antibakteri baru terus dilakukan karena banyak bakteri patogen telah resisten terhadap antibiotik. Mikrobioma dalam kapang tanah mempunyai potensi sebagai sumber antibakteri dengan menghasilkan metabolit sekunder. Penelitian ini bertujuan untuk mengisolasi kapang asal tanah Arboretum Fakultas Kehutanan, Institut Pertanian Bogor. Sebanyak $\pm 7,5 \mathrm{~g}$ sampel tanah diambil dari beberapa titik di Arboretum Fakultas dengan kedalaman maksimal $15 \mathrm{~cm}$ dari permukaan. Isolat kapang yang telah didapatkan, selanjutnya dikultivasi selama 28 hari menggunakan waterbath shaker. Miselium dan filtrat tanah hasil kultivasi dipisahkan dan diekstraksi dengan metode dan pelarut yang berbeda, sebelum diuji aktivitas antibakterinya menggunakan metode agar well diffusion. Sebanyak 6 isolat dari genus Aspergilus, Penicillium, Paecilomyces, dan Verticilium digunakan pada penelitian ini. Kultivasi dengan media sabouraud dextrose broth (SDB) yang mengandung pepton dan dekstrosa pada suhu $25^{\circ} \mathrm{C}$ mampu merangsang kapang pada penelitian ini untuk menghasilkan metabolit sekunder yang memiliki sifat antibakteri yang baik terhadap bakteri uji yang digunakan. Uji aktivitas antibakteri pada ekstrak miselium dan ekstrak filtrat tanah menunjukkan bahwa semua isolat kapang asal tanah mempunyai aktivitas antibakteri terhadap bakteri Staphylococcus aureus dan Escherichia coli. Filtrat tanah dengan kode isolat 103A memiliki zona hambat terbesar terhadap kedua jenis bakteri patogen yang diuji.
\end{abstract}

Kata kunci: antibakteri, filtrat tanah, kapang asal tanah, miselium

\section{ABSTRACT}

Research to discover new antibacterial agent has been increasing due to the increasing number of pathogenic bacteria become antibiotic-resistant. Microbiomes in soil mold have antibacterial potency by producing secondary metabolites. The aim of this research was to isolate soil molds from the Faculty of Forestry Arboretum at IPB University. Arboretum's soil was sampled $\pm 7.5 \mathrm{~g}$ from several points with maximum depth of $15 \mathrm{~cm}$ from surface. Mold isolate were cultivated for 28 days using waterbath shaker. Cultivated mycelium and soil filtrate were then separated and extracted using different methods and solvents, prior to antibacterial activity test using agar well diffusion method. Six isolates from Aspergillus, Penicillium, Paecilomyces, and Verticilium were used in this research. Cultivatation using sabouraud dextrose broth (SDB) contains pepton and dextrose in $25^{\circ} \mathrm{C}$ capable of stimulating mold growth. The research showed the result of secondary metabolit had antibacterial characteristic toward tested bacteria. The results of antibacterial activity test on both mycelium and soil filtrate extract showed that soil mold isolates had antibacterial activity against Staphylococcus aureus and Escherichia coli. Isolate 103A originated from soil filtrate formed the largest inhibition zone on both tested pathogens.

Keywords: antibacteria, mycelium, soil filtrate, soil mold

\section{PENDAHULUAN}

Antibakteri merupakan salah satu golongan antibiotika yang sering digunakan, baik pada manusia maupun hewan untuk tujuan medis, seperti terapi atau pencegahan. Antibakteri juga dapat digunakan dalam bidang pertanian, bioteknologi, dan rekayasa genetika untuk mencegah kejadian kontaminasi. Menurut Margiono (2008), penggunaan antibakteri saat ini lebih dari 40.000 ton/tahun dalam industri pangan, per-

1 Mahasiswa Fakultas Kedokteran Hewan, Institut Pertanian Bogor, Kampus IPB Darmaga, Bogor 16680

2 Divisi Mikrobiologi Medik, Departemen IImu Penyakit Hewan dan Kesehatan Masyarakat Veteriner, Fakultas Kedokteran Hewan, Institut Pertanian Bogor, Bogor 16680

* Penulis Korespondensi: Email: rizaldwinto@gmail.com tanian, peternakan, kesehatan, biokimia, genetika, dan biologi molekuler.

Pada saat ini, banyak bakteri-bakteri patogen, seperti Staphylococcus aureus ( $S$. aureus), Escherichia coli (E. coli), dan Salmonella sp., yang telah resisten terhadap berbagai antibakteri. Resistensi ini terjadi karena penggunaan antibiotik yang tidak tepat dan kurang bijak. Sifat resistensi bakteri terhadap beberapa antibakteri menjadi masalah serius, terutama berkaitan dengan pengobatan dan penanggulangan beberapa penyakit (Krisnaningsih et al. 2005).

Penelitian untuk menemukan senyawa metabolit yang memiliki aktivitas antibakteri baru terus dilakukan hingga saat ini. Penemuan antibakteri dapat dilakukan melalui sintesis kimia, biokimia baru, atau penemuan isolat mikrob baru (Tscherter \& Dreyfus 1992). Tanah merupakan salah satu sumber mikrob yang berpotensi 
menghasilkan antibakteri. Salah satu jenis mikrob pada tanah yang memiliki potensi menghasilkan antibakteri adalah kapang. Kapang melakukan kompetisi dengan mikroorganisme lain dengan cara menghasilkan antibakteri berupa metabolit sekunder, yaitu suatu bahan yang tidak digunakan untuk pertumbuhan, melainkan untuk pertahanan. Salah satu tanah yang mempunyai potensi untuk menghasilkan antibakteri adalah tanah yang berasal dari Arboretum. Arboretum adalah tempat berbagai pohon ditanam dan dikembangbiakkan untuk tujuan penelitian sehingga memiliki keragaman biodiversitas tanaman yang tinggi. Penelitian ini bertujuan untuk mengisolasi kapang asal tanah Arboretum Fakultas Kehutanan, Institut Pertanian Bogor yang berpotensi menghasilkan metabolit sekunder sebagai antibakteri terhadap $S$. aureus dan E. coli.

\section{METODE PENELITIAN}

\section{Waktu dan Tempat Penelitian}

Penelitian dilakukan selama periode SeptemberNovember 2017. Pengambilan sampel tanah penelitian dilakukan di Arboretum Fakultas Kehutanan, Institut Pertanian Bogor. Isolasi sampel tanah, kultivasi, dan ekstraksi, serta pengujian metabolit sekunder yang dihasilkan dilakukan di Laboratorium Bakteriologi, Laboratorium Mikologi, dan Laboratorium Terpadu Divisi Mikrobiologi Medik, Departemen IImu Penyakit Hewan dan Kesehatan Masyarakat Veteriner, Fakultas Kedokteran Hewan, Institut Pertanian Bogor.

\section{Alat dan Bahan}

Alat yang digunakan pada penelitian adalah kulkas, inkubator $37^{\circ} \mathrm{C}$, mikropipet $25-200 \mu \mathrm{L}$, bunsen, cover glass, object glass, ose, cawan petri, mikroskop, pipet volumetrik, tabung Durham, tabung sentrifus plastik, labu Erlenmeyer, skalpel, pinset, waterbath shaker, vortex mixer, pipa U, kertas saring, tabung Schott, cotton bud steril, tip steril, timbangan digital, corong pisah, rotary evaporator, laminar air flow, tabung reaksi, gelas ukur, dan corong.

Bahan yang digunakan pada penelitian ini adalah sampel tanah, Sabouraud dextrose agar (SDA), Sabouraud dextrose broth (SDB), lactophenol cotton blue (LPCB), xylol, Mueller-Hinton agar (MHA), alkohol $70 \%$, metanol, etil asetat, diklorometana, akuades steril, 0,5 McFarland, tryptone soya agar (TSA), bakteri uji $S$. aureus dan E. coli, dan cakram antibakteri kloramfenikol $30 \mu \mathrm{g}$.

\section{Prosedur Penelitian}

\section{- Pengambilan sampel tanah}

Pengambilan sampel tanah dilakukan di Arboretum Fakultas Kehutanan, Institut Pertanian Bogor pada bulan September 2017. Pengambilan tanah dilakukan pada kedalaman maksimal $15 \mathrm{~cm}$ di bawah permukaan tanah. Pengambilan dilakukan dengan membagi daerah pengambilan (utara, barat, timur, dan selatan) dan sampel diambil dari tanah di bawah pohon. Tanah diambil dari masing-masing titik area sebanyak $\pm 7.5 \mathrm{~g}$, selanjutnya disimpan dalam kantong plastik dan dibawa ke laboratorium.

\section{- Isolasi kapang tanah}

Bobot sampel sebesar 7,5 g diukur menggunakan timbangan digital. Setelah itu, tanah dimasukkan ke dalam tabung sentrifus plastik dan ditambahkan akuades steril sebanyak $17,5 \mathrm{~mL}$. Selanjutnya tanah dihomogenkan dengan menggunakan vortex mixer selama 15 menit.

Pengenceran sampel tanah dilakukan sampai $10^{-6}$. Sebanyak 6 buah tabung reaksi yang berisi $9 \mathrm{~mL}$ akuades steril disiapkan untuk proses pengenceran. Sampel tanah yang telah diencerkan dimasukkan ke dalam tabung pertama sebanyak $1 \mathrm{~mL}$ dan dihomogenkan dengan menggunakan vortex mixer selama 5 menit. Selanjutnya, sebanyak $1 \mathrm{~mL}$ dari sampel tabung pertama diambil dan dimasukkan ke tabung kedua. Prosedur yang sama dilakukan hingga tabung keenam.

Pengenceran yang digunakan pada penelitian ini adalah $10^{-3}, 10^{-4}, 10^{-5}$, dan $10^{-6}$. Masing-masing pengenceran dibiakkan pada media SDA. Inkubasi dilakukan pada suhu ruang $\left(25^{\circ} \mathrm{C}\right)$ selama 10 hari dan diamati perkembangannya setiap hari. Setelah 10 hari, kapang yang telah tumbuh disubkultur untuk mendapatkan isolat murni dan kultivasi.

\section{- Kultivasi metabolit sekunder kapang tanah}

Kultivasi metabolit sekunder dilakukan menurut Ho et al. (2003). Kapang ditumbuhkan pada media SDA yang baru, selanjutnya kapang dipotong sebesar $5 \times 5$ $\mathrm{mm}^{2}$ dan dimasukkan ke dalam botol Schott yang berisi $100 \mathrm{~mL}$ SDB. Kapang dalam SDB diinkubasi pada waterbath shaker dengan kecepatan 120 rpm pada suhu $25^{\circ} \mathrm{C}$ tanpa pencahayaan selama 28 hari.

\section{- Ekstraksi metabolit sekunder kapang tanah}

Kapang hasil kultivasi disaring dengan kertas saring untuk memisahkan antara filtrat dan miselium. Ekstraksi metabolit sekunder kapang mengacu pada metode Nursid et al. (2010). Proses ekstraksi dibagi menjadi 2 tahap, yaitu ekstraksi miselium kapang dan ekstraksi filtrat hasil kultivasi.

Ekstraksi pada miselium kapang dilakukan dengan metode maserasi. Miselium dipindahkan ke dalam labu Erlenmeyer yang berisi pelarut sebanyak $50 \mathrm{~mL}$. Pelarut yang digunakan adalah metanol dan diklorometana dengan perbandingan 1:1. Pelarut diganti setiap 24 jam dengan cara menyaring ekstrak menggunakan kertas saring sampai didapatkan filtrat. Proses ini diulang sebanyak 3 kali.

Proses ekstraksi filtrat dilakukan dengan menggunakan ekstraksi cair-cair. Filtrat dimasukkan ke dalam corong pisah yang telah ditambahkan pelarut. Pelarut yang digunakan adalah etil asetat sebanyak 50 $\mathrm{mL}$. Corong pisah selanjutnya dikocok selama 2 menit, setelah itu corong pisah didiamkan sampai terbentuk lapisan pemisah antara etil asetat dan filtrat. Proses ini dilakukan 3 kali pengulangan. 
Filtrat miselium dan filtrat hasil ekstraksi selanjutnya dilakukan pemekatan. Pemekatan bertujuan untuk mengurangi pelarut dan meningkatkan konsentrasi senyawa aktif dalam metabolit sekunder. Pemekatan dilakukan dengan menggunakan rotary evaporator pada suhu $20-40^{\circ} \mathrm{C}$ sampai mengental. Ekstrak filtrat dan miselium setelah dilakukan pemekatan dimasukkan ke tabung Eppendorfdan disimpan pada suhu $4^{\circ} \mathrm{C}$. Hasil rendemen dan waktu yang dibutuhkan untuk pemekatan dapat dilihat pada Tabel 1.

\section{- Pengujian aktivitas antibakteri metabolit sekunder kapang tanah}

Pengujian daya kerja metabolit sekunder kapang dilakukan dengan mengacu pada metode agar well diffusion (Balouri et al. 2016). Bakteri uji diremajakan terlebih dahulu dengan cara membiakkan bakteri uji pada media TSA selama 18 jam. Selanjutnya bakteri uji dibuat suspensi dalam akuades dengan tingkat kekeruhan sesuai dengan tabung 0,5 McFarland. Setelah itu, suspensi bakteri uji digoreskan di atas permukaan MHA secara merata dan didiamkan selama beberapa menit. Kemudian pada media MHA tersebut dibuat 6 buah sumur dengan bantuan tabung Durham.

Uji aktivitas antibakteri dilakukan dengan 3 perlakuan, yaitu filtrat tanpa ekstraksi, ekstrak filtrat, dan ekstrak miselium. Bakteri uji yang digunakan adalah $S$. aureus yang merupakan bakteri Gram positif dan $E$. coli dari golongan Gram negatif. Sebanyak $25 \mu \mathrm{L}$ masing-masing filtrat tanpa ekstraksi, ekstrak filtrat, dan ekstrak miselium yang telah dipekatkan dimasukkan ke dalam sumur yang berbeda. Kontrol positif diletakkan di bagian tengah cawan dan kontrol negatif diletakkan pada salah satu bagian dalam cawan petri. Semua media selanjutnya disimpan dalam inkubator $37^{\circ} \mathrm{C}$ selama 24 jam. Selanjutnya, hasil pengujian daya kerja metabolit sekunder kapang dan antibakteri kloramfenikol terhadap bakteri uji diamati dengan cara mengukur diameter zona hambat. Pengulangan dilakukan sebanyak 3 kali untuk masing-masing bakteri uji.

\section{Pengolahan Data}

Data yang diperoleh dari pengukuran diameter zona hambat pertumbuhan bakteri uji kemudian diolah menggunakan Microsoft Excel 2013 secara deskriptif dan disajikan dalam bentuk tabel dan gambar.

\section{HASIL DAN PEMBAHASAN}

Terdapat 16 isolat kapang dari sampel tanah yang didapatkan. Isolat kapang yang didapatkan merupakan kapang dari genus Aspergillus, Fusarium, Paecilomyces, Penicillium, Scopluariopsis, Trichoderma, dan Verticillium. Berdasarkan studi pustaka, diputuskan hanya 6 isolat kapang yang digunakan untuk penelitian ini. Dasar pemilihan kapang tersebut ialah karena genus tersebut sudah diketahui sebagai penghasil metabolit sekunder yang bersifat antibakteri yang digunakan dalam penelitian. Genus dari 6 isolat kapang yang digunakan berasal dari genus Aspergillus, Penicillium, Paecilomyces, dan Verticillium. Kapang yang terpilih dikultivasi untuk menghasilkan metabolit sekundernya.

\section{Kultivasi Kapang Tanah dan Ekstraksi Metabolit Sekundernya}

Kultivasi dan ekstraksi dilakukan terhadap 6 isolat kapang yang telah diisolasi dari sampel tanah Arboretum Fakultas Kehutanan, Institut Pertanian Bogor. Isolat kapang tersebut antara lain adalah 103A, 103F, 105A, 106B, 106C, dan 106F. Koloni kapang hasil isolasi pada media SDA dipotong sebesar $5 \times 5$ $\mathrm{mm}^{2}$ dan dimasukkan ke dalam botol Schott yang berisi SDB. Kapang dalam SDB diinkubasi pada waterbath shaker pada suhu $25^{\circ} \mathrm{C}$ selama 28 hari dengan kecepatan $120 \mathrm{rpm}$.

Rendemen yang dihasilkan oleh ekstrak filtrat dan miselium sangat sedikit. Hal ini menunjukkan bahwa isolat kapang masih belum mampu menghasilkan metabolit sekunder dalam jumlah banyak. Menurut Elias et al. (2006), faktor-faktor yang dapat memengaruhi produksi metabolit yang dihasilkan ialah nutrisi pada media, masa inkubasi, $\mathrm{pH}$, dan suhu.

Berdasarkan hasil yang didapatkan, waktu yang dibutuhkan untuk pemekatan ekstrak filtrat lebih lama daripada ekstrak miselium. Hal ini terjadi akibat perbedaan titik didih pelarut yang digunakan (Skoog et al. 2004). Pelarut yang digunakan pada ekstrak miselium adalah diklorometana dan metanol, sedangkan pelarut yang digunakan untuk ekstrak filtrat adalah etil asetat. Etil asetat memiliki titik didih sebesar $77^{\circ} \mathrm{C}$, sementara diklorometana mempunyai titik didih sebesar $40^{\circ} \mathrm{C}$, dan metanol memiliki titik didih sebesar $65^{\circ} \mathrm{C}$ (NCBI 2017).

Tabel 2 Rendemen dan lama pemekatan ekstrak filtrat tanah dan miselium pada berbagai isolat kapang

\begin{tabular}{|c|c|c|c|c|}
\hline \multirow{2}{*}{ Kode isolat } & \multicolumn{2}{|c|}{ Filtrat tanah } & \multicolumn{2}{|c|}{ Miselium } \\
\hline & Rendemen $(\% \mathrm{~b} / \mathrm{b})$ & Waktu & Rendemen (\% b/b) & Waktu \\
\hline $103 A$ & 0,84 & 43 menit & 3,76 & 32 menit \\
\hline $103 \mathrm{~F}$ & 1,10 & 46 menit & 8,19 & 29 menit \\
\hline $105 \mathrm{~A}$ & 1,61 & 51 menit & 3,58 & 25 menit \\
\hline $106 \mathrm{~B}$ & 0,45 & 44 menit & 2,99 & 30 menit \\
\hline $106 C$ & 0,47 & 40 menit & 4,81 & 29 menit \\
\hline $106 \mathrm{~F}$ & 0,77 & 38 menit & 2,11 & 31 menit \\
\hline
\end{tabular}




\section{Pengujian Aktivitas Antibakteri Metabolit Sekunder Kapang Tanah}

Zona hambat terbentuk akibat produksi senyawa metabolit sekunder oleh kapang yang menghambat pertumbuhan bakteri. Semakin besar diameter zona hambat yang terbentuk maka semakin kuat aktivitas antibakteri yang dihasilkan (Valgas et al. 2007). Rataan diameter zona hambat masing-masing ekstrak metabolit sekunder kapang terhadap bakteri uji disajikan pada Tabel 2. Hasil pengujian aktivitas antibakteri menunjukkan bahwa metabolit sekunder yang dihasilkan dari tiap isolat dapat menghambat pertumbuhan. Zona hambat yang terbentuk dari setiap bakteri uji dapat dilihat pada Gambar 1 dan 2.

Hasil uji menunjukkan bahwa filtrat tanah tanpa ekstraksi dengan kode isolat 103A, 103F, dan 106C mempunyai aktivitas antibakteri. Demikian juga pada semua ekstrak filtrat dan ekstrak miselium dalam penelitian ini menunjukkan adanya zona hambat terhadap bakteri uji $S$. aureus dan E. coli. Menurut Joe et al. (2009), diameter zona hambat yang lebih dari $12 \mathrm{~mm}$ menunjukkan bahwa bahan yang diuji mempunyai aktivitas antibakteri yang sangat kuat, sedangkan zona hambat yang terbentuk kurang dari $7 \mathrm{~mm}$ menunjukkan bahwa bahan yang diuji tidak mempunyai aktivitas antibakteri. Berdasarkan penggolongan tersebut, dapat dikatakan bahwa hampir semua isolat mempunyai aktivitas antibakteri yang sangat kuat terhadap bakteri uji $S$. aureus dan $E$. coli. Isolat $103 \mathrm{~A}$ mempunyai zona hambat yang paling besar baik pada bakteri uji $S$. aureus maupun $E$. coli yang ditunjukkan dengan ukuran zona hambat yang terbentuk sebesar 41,00 $\pm 2,65$ $\mathrm{mm}$ pada $S$. aureus dan $45,00 \pm 3,00 \mathrm{~mm}$ pada $E$. coli.
Kontrol positif yang digunakan pada penelitian ini adalah kloramfenikol. Kloramfenikol merupakan antibakteri berspektrum luas, yaitu dapat membunuh bakteri Gram positif dan Gram negatif (Hauser 2013). Zona hambat yang terbentuk oleh antibakteri kloramfenikol pada bakteri uji $E$. coli adalah sebesar 26,22 \pm $1,72 \mathrm{~mm}$ dan pada $S$. aureus adalah sebesar 33,56 \pm $1,94 \mathrm{~mm}$. Menurut CLSI (2015), kloramfenikol masih dapat dinyatakan sensitif jika zona hambat yang terbentuk lebih dari $18 \mathrm{~mm}$ untuk bakteri $E$. coli dan $S$. aureus. Berdasarkan hasil yang didapatkan dalam penelitian ini, kloramfenikol masih bersifat sensitif terhadap bakteri uji $S$. aureus dan E. coli.

Bahan pelarut yang digunakan untuk mengekstraksi metabolit sekunder kapang digunakan sebagai kontrol negatif. Ekstrak filtrat menggunakan etil asetat sebagai kontrol negatif, sedangkan ekstrak miselium menggunakan diklorometan dan metanol sebagai kontrol negatif. Hasil penelitian menunjukkan etil asetat tidak membentuk zona hambat pada bakteri uji yang ditunjukkan dengan nilai zona hambat sebesar 6,00 \pm $0,00 \mathrm{~mm}$ sesuai dengan diameter sumuran, sedangkan campuran diklorometan dan metanol membentuk zona hambat sebesar $8,00 \pm 0,00 \mathrm{~mm}$ pada bakteri uji $S$. aureus dan $8,80 \pm 0,10 \mathrm{~mm}$ pada bakteri uji $E$. coli. Menurut Andriani et al. (2016), etil asetat tidak membentuk zona hambat terhadap bakteri Gram positif dan Gram negatif. Penbentukan zona hambat pada campuran diklorometana dan metanol dapat disebabkan oleh keberadaan metanol yang merupakan salah satu senyawa kimia yang berasal dari golongan alkohol gugus hidroksil. Golongan alkohol, terutama etanol, sering dijadikan antiseptik karena mempunyai aktivitas

Tabel 3 Rataan diameter zona hambat kapang terhadap bakteri uji.

\begin{tabular}{|c|c|c|c|}
\hline \multirow{2}{*}{$\begin{array}{l}\text { Kode } \\
\text { Isolat }\end{array}$} & \multirow{2}{*}{ Ekstraksi } & \multicolumn{2}{|c|}{ Diameter Zona Hambat (mm) } \\
\hline & & S. aureus & E. coli \\
\hline \multirow{3}{*}{$103 \mathrm{~A}$} & Filtrat tanpa ekstraksi (C1) & $22,00 \pm 1,00$ & $31,00 \pm 2,00$ \\
\hline & Ekstrak filrat tanah (S1) & $41,00 \pm 2,65$ & $45,00 \pm 3,00$ \\
\hline & Ekstrak miselium (M1) & $26,67 \pm 1,53$ & $32,67 \pm 1,53$ \\
\hline \multirow{3}{*}{$103 \mathrm{~F}$} & Filtrat tanpa ekstraksi (C2) & $21,67 \pm 1,15$ & $32,67 \pm 1,15$ \\
\hline & Ekstrak filrat tanah (S2) & $39,00 \pm 1,00$ & $44,00 \pm 2,00$ \\
\hline & Ekstrak miselium (M2) & $28,33 \pm 0,58$ & $37,33 \pm 1,15$ \\
\hline \multirow{3}{*}{$105 \mathrm{~A}$} & Filtrat tanpa ekstraksi (C3) & $6,00 \pm 0,00$ & $6,00 \pm 0,00$ \\
\hline & Ekstrak filrat tanah (S3) & $13,00 \pm 1,00$ & $23,00 \pm 1,00$ \\
\hline & Ekstrak miselium (M3) & $9,00 \pm 2,65$ & $29,00 \pm 7,81$ \\
\hline \multirow{3}{*}{$106 \mathrm{~B}$} & Filtrat tanpa ekstraksi (C4) & $6,00 \pm 0,00$ & $6,00 \pm 0,00$ \\
\hline & Ekstrak filrat tanah (S4) & $28,33 \pm 0,58$ & $35,33 \pm 1,15$ \\
\hline & Ekstrak miselium (M4) & $21,67 \pm 0,58$ & $9,00 \pm 1,00$ \\
\hline \multirow{3}{*}{$106 C$} & Filtrat tanpa ekstraksi (C5) & $14,33 \pm 0,58$ & $6,00 \pm 0,00$ \\
\hline & Ekstrak filrat tanah (S5) & $29,67 \pm 1,53$ & $39,67 \pm 3,51$ \\
\hline & Ekstrak miselium (M5) & $19,67 \pm 2,52$ & $12,00 \pm 0,00$ \\
\hline \multirow{3}{*}{$106 \mathrm{~F}$} & Filtrat tanpa ekstraksi (C6) & $6,00 \pm 0,00$ & $6,00 \pm 0,00$ \\
\hline & Ekstrak filrat tanah (S6) & $15,00 \pm 2,65$ & $17,33 \pm 3,51$ \\
\hline & Ekstrak miselium (M6) & $14,33 \pm 2,08$ & $18,33 \pm 3,21$ \\
\hline \multicolumn{2}{|c|}{ Kontrol positif (Kloramfenikol) } & $26,22 \pm 1,72$ & $33,56 \pm 1,94$ \\
\hline \multicolumn{2}{|c|}{ Kontrol negatif filtrat } & $6,00 \pm 0,00$ & $6,00 \pm 0,00$ \\
\hline \multicolumn{2}{|c|}{ Kontrol negatif miselium } & $8,00 \pm 0,00$ & $8,80 \pm 0,10$ \\
\hline
\end{tabular}

Keterangan: Nilai 6,00 menunjukkan tidak terbentuknya zona hambat atau sama dengan diameter sumuran. 

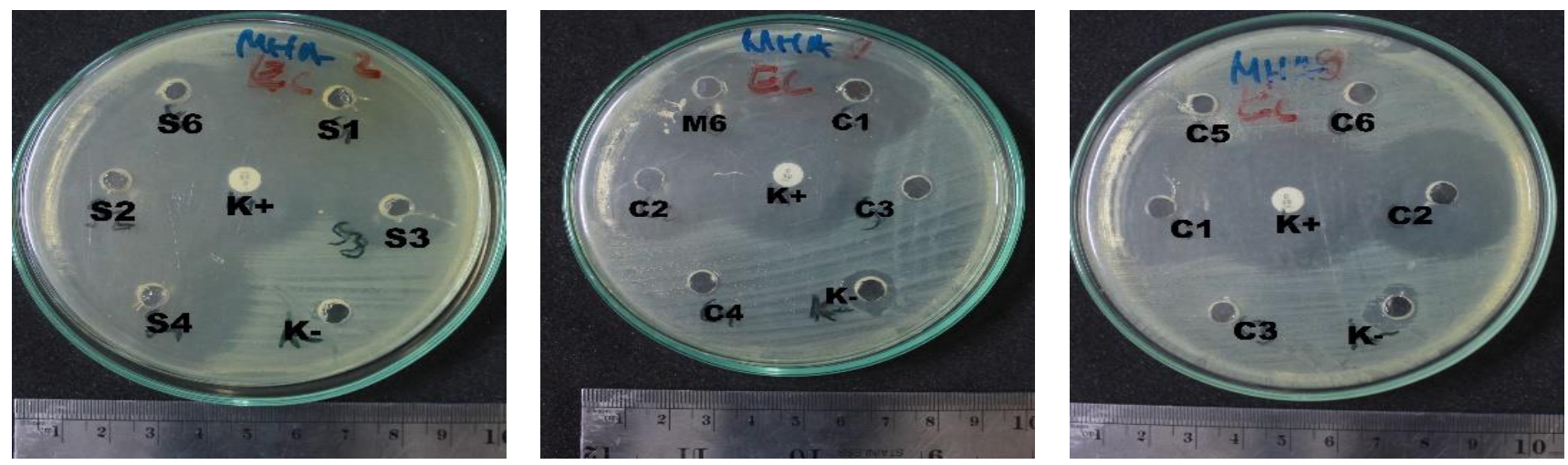

Gambar 1 Zona hambat yang terbentuk pada bakteri uji E. coli.
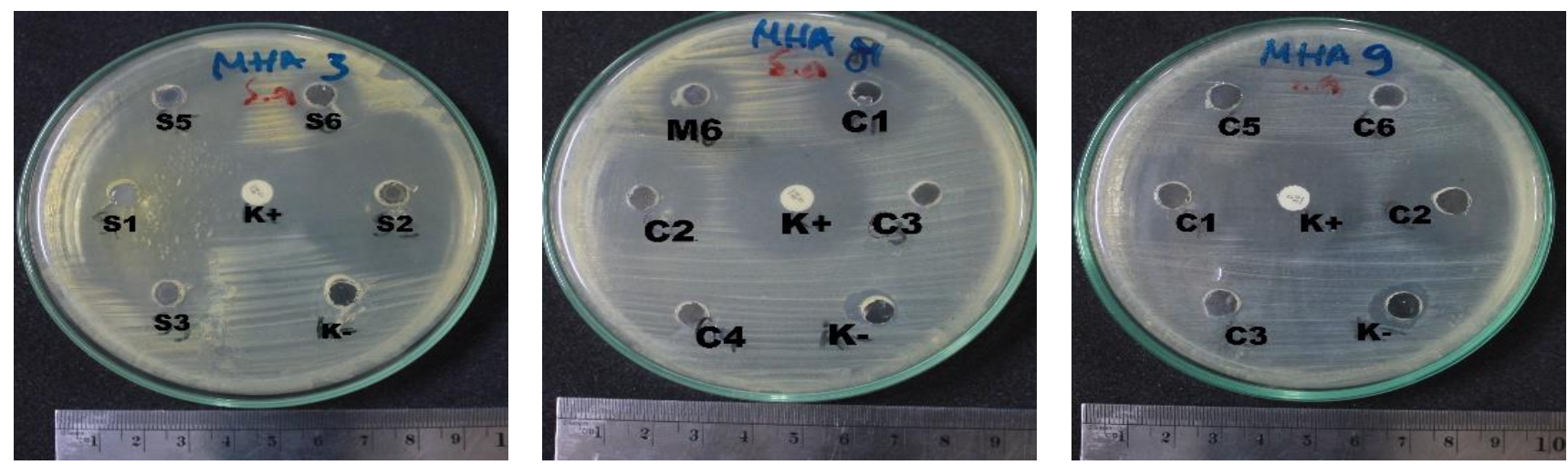

Gambar 2 Zona hambat yang terbentuk pada bakteri uji S. aureus.

antibakteri dan aman untuk jaringan hidup, seperti kulit (Russell \& McDonell 1999).

Terdapat aktivitas antibakteri yang berbeda-beda untuk setiap bakteri uji $S$. aureus dan $E$. coli. Hal ini disebabkan oleh perbedaan komponen dinding sel bakteri tersebut. Dinding sel bakteri Gram negatif terdiri atas outer membrane, murein atau peptidoglikan (5\%), celah periplasma, dan membran sitoplasma, sedangkan dinding sel bakteri Gram positif terdiri atas murein atau peptidoglikan (95\%) dan membran sitoplasma (Tille 2013). Adanya aktivitas antibakteri dari setiap ekstrak kapang terhadap $S$. aureus dan $E$. coli disebabkan oleh senyawa kimia yang terkandung di dalam ekstrak tersebut memiliki sifat polaritas yang hampir sama dengan setiap membran luar bakteri. Hal ini menyebabkan ekstrak mudah masuk ke dalam membran dinding sel bakteri Gram positif dan Gram negatif (Mambang et al. 2014). Faktor lain yang memengaruhi aktivitas senyawa antibakteri dari setiap ekstrak adalah aktivitas metabolisme bakteri dan strain bakteri uji (Siregar et al. 2012).

Beberapa senyawa antibakteri dapat ditemukan di dalam kapang. Penelitian yang dilakukan oleh Kasanah et al. (1998) menemukan kapang Aspergillus sp. menghasilkan senyawa antimikrob yang bersifat netral, polar, dan memiliki gugus fenol. Gugus fenol mampu mendenaturasi protein pada dinding dan membran sel bakteri. Tricothene yang dihasillkan Scopulariopsis sp. mampu menghambat pertumbuhan bakteri Gram positif dan Gram negatif, selain itu senyawa Paecilospirone, Cephalosporin C, dan Verticilin
$A$ yang dihasilkan oleh kapang dari jenis yang berbeda dapat menghasilkan senyawa yang bersifat antibakteri. Penelitian ini masih belum dapat menentukan senyawa-senyawa atau bahan aktif yang terkandung dalam setiap ekstrak metabolit sekunder kapang yang berfungsi sebagai antibakteri.

\section{KESIMPULAN}

Sebanyak 16 isolat kapang didapatkan dari sampel tanah yang digunakan, 6 di antaranya digunakan dalam penelitian ini yang berasal dari genus Aspergillus, Penicillium, Paecilomyces, dan Verticillium. Kultivasi dengan media sabouraud dextrose broth (SDB) yang mengandung pepton dan dekstrosa pada suhu $25^{\circ} \mathrm{C}$ mampu merangsang kapang pada penelitian ini untuk menghasilkan metabolit sekunder yang memiliki sifat antibakteri yang baik terhadap bakteri uji yang digunakan. Semua ekstrak filtrat tanah dan miselium memiliki aktivitas antibakteri yang ditunjukkan dengan pembentukan zona hambat terhadap pertumbuhan bakteri uji $S$. aureus dan E. coli. Ekstrak filtrat isolat kapang 103A, $103 \mathrm{~F}, 106 \mathrm{~B}, 106 \mathrm{C}$, serta isolat ekstrak miselium isolat kapang 103A dan 103F memiliki zona hambat yang lebih besar dibandingkan dengan kontrol positif antibakteri kloramfenikol terhadap bakteri $S$. aureus $(26,22 \pm 1,72 \mathrm{~mm})$. Ekstrak filtrat isolat kapang 103A, 103F, 106B, dan 106C memiliki zona hambat yang lebih besar dibandingkan dengan zona hambat kontrol 
positif antibakteri kloramfenikol terhadap bakteri $E$. coli $(33,56 \pm 1,94 \mathrm{~mm})$. Ekstrak filtrat tanah berkode isolat 103A memiliki zona hambat terbesar, baik terhadap bakteri $S$. aureus $(41,00 \pm 2,65 \mathrm{~mm})$ maupun $E$. coli $(45,00 \pm 3,00 \mathrm{~mm})$.

\section{DAFTAR PUSTAKA}

Andriani CR, Oesman F, Nursanty R. 2016. Uji zona hambat ekstrak etil asetat daun alpukat (Persea americana Mill.) terhadap pertumbuhan bakteri Staphylococcus aureus. Jurnal Kedokteran Syiah Kuala. 16(1):1-5.

Balouri M, Sadiki M, Ibnsouda SK. 2016. Methods for in vitro evaluating antimicrobial activity: a review. Journal of Pharmaceutical Analysis. 6: 71-79. https://doi.org/10.1016/j.jpha.2015.11.005

[CLSI] Clinical and Laboratory Standards Institute. 2015. Performance Standards for Antimicrobial Susceptibility Testing; Twenty-Fifth Informational Supplement. Wayne (US): Clinical and Laboratory Standards Institute.

Elias BC, Said S, Albuquerue S, Pupo MT. 2006. The influence of culture conditions of the biosynthesis of secondary metabolites by Penicilium verrucosum Dierck. Microbiological Research. 161: 273-280.

Hauser AR. 2013. Antibiotic Basic for Clinicians. Philadelphia (US): Lippincott Williams \& Wilkins. https://doi.org/10.1016/j.micres.2005.10.003

Ho WH, To PC, Hyde KD. 2003. Induction of antibiotic production of freshwater fungi using mix-culture fermentation. Fungal Diversity. 12: 45-51.

Joe MM, Jayachitra J, Vijayapriya M. 2009. Antimicrobial activity of some common spices against certain human pathogens. Journal of Medicinal Plants Research. 3(11): 1134-1136.

Kasanah N, Amini, Wahyono. 1998. Karakterisasi senyawa antimikroba isolate Aspergillus sp. hasil isolasi dari tanah. Majalah Farmasi. 9(4): 166-173.

Krisnaningsih MMF, Asmara W, Wibowo MH. 2005. Uji sensitivitas Escherichia coli patogen pada ayam terhadap beberapa jenis antibiotika. Journal Sains Veteriner. 1: 13-18.
Mambang DEP, Rosidah, Suryanto D. 2014. Aktivitas antibakteri ekstrak tempe terhadap bakteri Bacillus subtilis dan Staphylococcus aureus. Jurnal Teknologi dan Industri Pangan. 25(1): 115-118.

Margiono S. 2008. Produksi metabolit sekunder (antibiotika) oleh isolat jamur endofit Indonesia. Majalah Farmasi Indonesia. 19(2): 86-94.

[NCBI] National Center for Biotechnology Information. Compound summary for CID 6344. Pubchem Compound Database [Internet]. [diunduh $30 \mathrm{Nov}$ 2017]. compound/ 6344.

Nursid M, Pratitis A, Chasanah E. 2010. Kultivasi kapang MFW-01-08 yang diisolasi dari ascidia Aplidium longithorax dan uji aktivitas sitotoksiknya terhadap sel kanker payudara T47D. Jurnal Pascapanen dan Bioteknologi Kelautan dan Perikanan. 5(2): 103-110. https://doi.org/10.15578 /jpbkp.v5i2.412

Russell AD, McDonnell G. 1999. Antiseptics and Disinfectants: Activity, Action, and Resistance. Clinical Microbiol Review. 12 (1): 147-149. https:// doi.org/10.1128/CMR.12.1.147

Siregar AF, Sabdono A, Pringgenies D. 2012. Potensi antibakteri ekstrak rumput laut terhadap bakteri penyakit kulit Pseudomonas aeruginosa, Staphylococcus epidermidis, dan Micrococcus luteus. Journal of Marine Research. 1(2): 152-160.

Skoog DA, West DM, Holler FJ. Crouch SR. 2004. Fundamental of Analytical Chemistry $8^{\text {th }}$ Edition. Belmont (US): Brook/Cole-Thomson Learning.

Tille PM. 2013. Bailey and Scott Diagnostic Microbiology $13^{\text {th }}$ Edition. Missouri (US): Elsevier.

Tscherter H, Dreyfuss. 1992. New metabolites, processes for their production and uses. Patent Cooperation Treaty PCT International Publication. 38: 28-45.

Valgas C, Souza SM, Smania EFA, Smania JA. 2007. Screening methods to determine antibacterial activity of natural products. Brazillian Journal of Microbiology. 38: 369-380. https://doi.org/10. 1590/S1517-83822007000200034 